\title{
Effect of Nutrients on Growth, Flowering and Yield of African Marigold (Tagetes erecta L.) cv. Pusa Narangi Gainda
}

\author{
Ravindra Kumar, Ashok Kumar* and Abhinav Kumar
}

Department of Floriculture and Landscape, College of Horticulture \& Forestry, N.D. University of Agriculture and Technology, Faizabad, (U.P.) India

*Corresponding author

\section{A B S T R A C T}

\section{Keywords}

Marigold, Boron, Zinc, Magnesium sulphate

Article Info

Accepted: 02 May 2018 Available Online: 10 June 2018

\begin{abstract}
The experiment was conducted in Randomized Block Design with ten treatments comprising of 3 levels each of Urea (1.0, 2.0 and $3.0 \%), \mathrm{MgSO}_{4}(0.2,0.4$ and $0.6 \%)$ and Boron $(0.2,0.4$ and $0.6 \%)$ replicated thrice to evaluate the effect of nutrients on growth, flowering attribute and yield characters in African marigold. Among all the treatments urea $(0.2 \%)$ resulted in the maximum plant height, plant spread, maximum number of branches, early flower bud initiation, opening of first flower, maximum duration of flowering, number of flower per plant, flower stalk length, weight of flower, weight of flower per plant and flower yield per hectare.
\end{abstract}

\section{Introduction}

Marigold (Tagetes erecta Linn.) is an important commercial flower of India, belongs to family Asteraceae (Compositeae). The common name 'marigold' derived from 'Mary's Gold' is associated with Virgin Mary of the Christian stories. It was originated in central and south America especially Mexico. In India marigold is one of the most commonly grown flowers. Because of their easy in cultivation, wide adaptability to varying soil and climatic condition, long duration of flowering and attractively colours flower of excellent keeping quality. Marigold can be grown in all seasons i.e., rainy, winter and summer of which rainy and winter season crops are the main crops under eastern U.P. condition. Seedlings are transplanted in the month of July-August and SeptemberOctober, respectively, while summer season crop is transplanted in the month of FebruaryMarch. Marigold is mainly grown in India, Tropical Africa, Sri Lanka and Madagascar. India occupies 15 percent area for traditional flower in the world (Jawahar, 2004). Major marigold producing states are Tamil Nadu, Karnataka, Andhra Pradesh, Maharashtra, West Bengal, Orissa, Delhi, U.P and Uttarakhand. The marigold is one of the most popular flowers in our country and used extensively on religious and social functions in different forms, flowers are sold in the market as loose flower or as garlands making. Nitrogen is an important metabolic element for growth and development of plant. It is 
essentially considered as metabolic activities, transformation of energy, essential for metabolism of protein and other biochemical product such as nucleic acid, chlorophyll and protoplasm. Foliar application of magnesium sulphate represents a means of ameliorating the nutritional status of crops growing under conditions of deficiency.

Foliar application of $\mathrm{Mg}$ has been demonstrated to increase the chlorophyll concentration and vegetative yield of plants and it is constituent of chlorophyll, chromosomes polyribosome and carrier of $\mathrm{P}$ in plants particularly in concentration with the formation of the seeds of high oil content; promotes formation oil and fats, translocation of starches, catalytic action. The role of Boron is the maintenance of cell wall integrity through binding to pectic polysaccharides.

Boron is involved in plant processes such as sugar translocation and membrane permeability, leaf photosynthesis, cell elongation and division, cell wall biosynthesis, nitrogen fixation, protein, amino acids and nitrate metabolism. It also produces direct influence on flower development, pollen germination, fertilization, seed development and fruit abscission. Boron is an essential element found in the meristematic regions of plant such as root tips, emerging leaves and buds. Keeping in view the role of these nutrients, present investigation was conducted to assess the effect urea, magnesium sulphate and boron spraying on marigold.

\section{Materials and Methods}

An experiment was conducted during winter season of 2014- 15 at main experiment station Department of Floriculture and Landscape, of University. Geographically, it is situated in typical saline alkali belt of Indo-gangetic plains of eastern U.P. at 26.47-0 N latitude, 88.120 E longitudes and at an altitude of 113 meter from mean sea level. The region enjoys sub humid and subtropical climate receiving a mean annual rainfall of about $1215 \mathrm{~mm}$ out of which about $85 \%$ is concentrated from mid June to end of September. The winter months are cold and dry and occasional frost occurs during this period. Westerly hot wind starts from the month of March and continues up to onset of monsoon. Recommended doses of NPK another input was applied at appropriate time. The treatments comprises three doses each of Urea (1.0, 2.0 and $3.0 \%), \mathrm{MgSO}_{4}$ $(0.2,0.4$ and $0.6 \%)$ and Boron $(0.2,0.4$ and $0.6 \%$ ) Spraying of nutrients was done 30 days after transplanting.

The experiment was laid out in a randomized block design with three replications having a plot size of $2.0 \times 1.60 \mathrm{~m}$. The 30 days old seedling of African marigold (Tagetes erecta L.) cv. Pusa Narangi Gainda was planted at a distance of 40 x $40 \mathrm{~cm}$. The important vegetative growth as plant height, plant spread, number of branches and flowering characters viz. days taken to first flower bud initiation, days taken to opening of first flower, duration of flowering, length of flower stalk $(\mathrm{cm})$, diameter of flower $(\mathrm{cm})$, number of flower per plant and yield characters such as weight of flower $(\mathrm{g})$, flowers yield per plant (g) and flower yield per hectare (q) were recorded in five randomly selected plants per replication in each treatment. The data were analyzed by method suggested by Fisher and Yates (1949).

\section{Results and Discussion}

The results presented in Table 1 indicated that variation in height of the plant influenced significantly by the foliar application of nutrients. The result shows height of plant at 75 DAT was significantly maximum (56.70 $\mathrm{cm})$ with application of urea at $2 \%$ spraying and found at par with boron $(0.4 \%)$ and boron $(0.6 \%)$. 
Table.1 Effect of nutrients on growth, flowering and yield of African marigold (Tagetes erecta L.)

\begin{tabular}{|c|c|c|c|c|c|c|c|c|c|c|c|}
\hline Treatments & $\begin{array}{l}\text { Plant } \\
\text { Height } \\
\text { (cm) }\end{array}$ & $\begin{array}{l}\text { Plant } \\
\text { sprea } \\
\text { d (cm) }\end{array}$ & $\begin{array}{c}\text { Number of } \\
\text { branches / } \\
\text { plant }\end{array}$ & $\begin{array}{l}\text { Days taken to } \\
\text { first flower } \\
\text { bud initiation }\end{array}$ & $\begin{array}{l}\text { Days taken to } \\
\text { Opening of } \\
\text { first flower }\end{array}$ & $\begin{array}{c}\text { Duration } \\
\text { of } \\
\text { flowering } \\
\text { (days) }\end{array}$ & $\begin{array}{l}\text { Length of } \\
\text { flower } \\
\text { stalk (cm) }\end{array}$ & $\begin{array}{l}\text { Diameter } \\
\text { of } \\
\text { Flower } \\
(\mathrm{cm})\end{array}$ & $\begin{array}{l}\text { Weight } \\
\text { of } \\
\text { Flower } \\
\text { (g) }\end{array}$ & $\begin{array}{c}\text { Number } \\
\text { of flower } \\
\text { / plant }\end{array}$ & $\begin{array}{c}\text { Flower } \\
\text { yield } \\
\text { (q/ha) }\end{array}$ \\
\hline $\mathbf{T}_{1}$ & 44.33 & 38.06 & 24.73 & 55.73 & 94.53 & 37.66 & 7.40 & 6.70 & 9.26 & 48.56 & 224.86 \\
\hline$\overline{T_{2}}$ & 51.73 & 39.20 & 25.56 & 54.66 & 94.33 & 39.33 & 7.60 & 7.11 & 10.51 & 51.55 & 271.00 \\
\hline$\overline{T_{3}}$ & 56.70 & 41.13 & 26.06 & 51.66 & 93.20 & 41.30 & 7.76 & 8.75 & 13.00 & 54.73 & 355.76 \\
\hline $\mathbf{T}_{4}$ & 51.40 & 38.33 & 25.26 & 55.33 & 94.53 & 39.80 & 7.70 & 7.55 & 11.02 & 51.09 & 281.53 \\
\hline$\overline{T_{5}}$ & 54.13 & 37.13 & 25.33 & 55.80 & 94.80 & 37.66 & 7.46 & 7.41 & 10.53 & 45.66 & 240.50 \\
\hline $\mathbf{T}_{6}$ & 48.66 & 39.53 & 25.60 & 58.33 & 94.93 & 38.80 & 7.60 & 7.96 & 11.03 & 53.63 & 295.86 \\
\hline $\mathbf{T}_{7}$ & 45.66 & 39.60 & 25.13 & 55.13 & 95.66 & 38.33 & 7.60 & 7.56 & 10.58 & 49.96 & 264.28 \\
\hline $\mathbf{T}_{8}$ & 54.26 & 35.66 & 24.66 & 55.26 & 95.20 & 37.86 & 7.62 & 7.72 & 11.11 & 46.02 & 255.73 \\
\hline$\overline{T_{9}}$ & 55.23 & 39.26 & 24.73 & 55.60 & 94.20 & 38.06 & 7.60 & 7.48 & 10.64 & 49.43 & 262.97 \\
\hline $\mathbf{T}_{10}$ & 55.76 & 38.93 & 24.80 & 53.53 & 95.20 & 38.20 & 7.52 & 7.40 & 10.51 & 49.20 & 258.63 \\
\hline S.Em \pm & 0.79 & 0.84 & 0.28 & 0.723 & 0.43 & 0.72 & 0.05 & 0.02 & 0.02 & 0.51 & 2.87 \\
\hline CD at $5 \%$ & 2.38 & 2.52 & 0.86 & 2.16 & 1.29 & 2.16 & 0.16 & 0.06 & 0.06 & 1.53 & 8.60 \\
\hline
\end{tabular}

Treatments: $\mathrm{T}_{1}$-Control, $\mathrm{T}_{2}-1 \%$ urea spraying, $\mathrm{T}_{3}-2 \%$ urea spraying, $\mathrm{T}_{4}-3 \%$ urea spraying, $\mathrm{T}_{5^{-}} 0.2 \% \mathrm{MgSO}_{4}, \mathrm{~T}_{6}-0.4 \% \mathrm{MgSO}_{4}, \mathrm{~T}_{7^{-}}-0.6 \% \mathrm{MgSO}_{4}, \mathrm{~T}_{8}-0.2 \% \mathrm{Boron}^{-}$ spraying, $\mathrm{T}_{9^{-}} 0.4 \%$ Boron spraying, $\mathrm{T}_{10^{-}} 0.6 \%$ Boron spraying. 
Effect of urea on growth of the plants that considered as metabolic activities, transformation of energy, essential for metabolism of protein and other biochemical product such as nucleic acid, chlorophyll and protoplasm and Boron is involved in plant processes such as sugar translocation and membrane permeability, leaf photosynthesis, cell elongation and division, cell wall biosynthesis and nitrate metabolism. Similar results were also reported by Dashora et al., (2004) and Jat and Gupta (2007) in African marigold, Kakade et al., (2009) in China aster and Reddy and Chaturvedi (2009) in Gladiolus. The spread of plant was recorded significantly maximum with the foliar application of urea $(2 \%)$ which was found at par with urea $(1 \%)$, $\mathrm{MgSO}_{4}(0.4 \%), \mathrm{MgSO}_{4}(0.6 \%)$, boron $(0.4 \%)$ and boron $(0.6 \%)$. while lowest plant spread was recorded in control. Urea resulted hyper elongation of internodal length caused extension in plant height while increase in total count of main axis consequently increased number of dormant buds from where primary branches originated which resulting optimum spread of plant. These findings are in close conformity with result of Nagaich et al., (2003) in marigold and Kakade et al., (2009) in China aster. The maximum numbers of branches were recorded with urea $(2 \%)$ which was found at par with urea $(1 \%)$, urea $(3 \%), \mathrm{MgSO}_{4}(0.2 \%)$ and $\mathrm{MgSO}_{4} \quad$ (0.4\%). Khan (2000) reported regulation of maximum number of branches per plant in dahlia with Zn @ 4\%, boron @ 0.2\% and Mn @ $0.2 \%$ treatment and reported increased number of main branches by Mathew et al., (2004) and Kumar et al., (2010) in marigold.

The earliest bud initiation and flowering was observed with the application of urea $2 \%$ followed by boron $0.6 \%$ and reduces Juvenile periods while maximum days taken to bud initiation was noted with the application of $\mathrm{MgSO}_{4} \quad 0.4 \%$. Function of nitrogen is the initiation of meristematic activity of plants. The cell division and cell enlargement are also accelerated by ample supply of nitrogen. Acharya et al., (2004) reported early flowering and maximum diameter of flower with application of nitrogen in Tagetes erecta, Singh et al., (2004) in Gladiolous and Muthumanickam et al., (1999) in Gerbera. Nitrogen was found most effective in extending the flowering duration especially with urea $2 \%$ followed by urea $3 \%$ and urea $1 \%$ and it might be due to advanced stage of flowering in marigold. Findings are similar to the findings of Muktanjali et al., (2004) in marigold Jauhari et al., (2005) in gladiolus. Significantly maximum length of flower stalk was recorded with foliar spray of urea 2\%. Yadav et al., (2000) also observed increased pedicel length in marigold with nitrogen in African marigold. Data presented in Table 1 clearly showed that the maximum numbers of flower per plant were recorded with foliar application of urea $2 \%$ followed by $\mathrm{MgSO}_{4} 0.4 \%$. The enhancement in number of flower per plant might be due to the production of large number of laterals at early stage of growth which had sufficient time to accumulate carbohydrate for proper flower bud differentiation due to enhanced reproductive efficiency and photosynthesis restricted plant type. The result was in close conformity with Barman et al., (1993) and Kumar et al., (2009) in chrysanthemum. Diameter of flower was found significantly maximum with urea $2 \%$ followed by $\mathrm{MgSO}_{4} 0.4 \%$ whereas minimum flower diameter was recorded under control.

It is evident from the data presented in Table 1 that weight of flower and yield of flower per ha was reported significantly maximum with foliar application of urea 2\%. Yadav et al., (2000) observed the increase flower weight with increasing nitrogen levels and maximum weight was obtained with application $180 \mathrm{ppm}$ nitrogen in marigold. Results are accordance to the findings of Bhattacharjee et al., (1992) in rose, Kumar et al., (2010) in marigold.

\section{References}

Acharya, M. M. and Dashora, L. K. 2004. Response of graded levels of nitrogen and phosphorus on vegetative growth and 
flowering in African marigold (Tagetes erecta L.). J. Orn. Hort., 7 (2): 179-18.

Barman, D. and Pal, P. 1993. Effect of micronutrients on growth and flowering of Chrysanthemum morifolium cv. Chandrama. Haryana J. Hort. Sci., 28: 78-79.

Bhattacharjee, S.K. and Singh, U.C.1992. Response to micronutrients spray on growth, flowering, flower quality and yield of "Raktagandha" rose. Orissa. J. Hort., 20: 58-63.

Dashora, R.M., Verma, P. and L.K. 2004. Effect of growth retardants and micronutrients on growth and yield of African marigold (Tagetes erecta L.) cv. Pusa Basanti. Sci. Hort. 9: 213-218.

Fisher, R.D. and Yates, F.1949. Statistical table for biological and medical research. Oliver and Boyd, Edberg (London): $3^{\text {rd }}$ edi.

Jat, K. and Gupta, K. N. 2007. Effect of foliar application of urea and zinc sulphate on growth and flowering parameters in African marigold (Tagetes erecta Linn.). J. Orn. Hort. 10(4): 271-273.

Jauhari, S., Srivastava, R. and Srivastava, P. C. 2005. Effect of Zinc on growth, flowering, corm attributes, post-harvest life, leaf and corm nutrients status in gladiolus cv. Red Beauty. Prog. Hort., 37(2): 423-428.

Jawahar, M. 2004.Traditional Floriculture. In: Emerging Trends in ornamental Horticulture. ISOH, New Delhi; 5-10.

Kakade, D. K., Rajput, S. G. and Joshi, K. L. 2009. Effect of foliar application of $\mathrm{Fe}$ and $\mathrm{Zn}$ on growth, flowering and Yield of China aster (Callistepus chinensis L. Nees). Asian J. Hort., 4: 138-140.

Khan, F.U. 2000. Effect of micronutrients on Dahlia. J. Orn. Hort. (New series), 3(2): 122-123.
Kumar, P. N., Misra, R. L., Dhiman, S. R., Ganga, M. and Lalitha, K. 2009. Effect of micronutrient sprays on growth and flowering of chrysanthemum. Ind. J. Agri. Sci., 79: 426-428.

Kumar, P., Kumar J., Umrao, and Rajbeer, V. K. 2010. Effect of nitrogen and iron on growth and flowering parameters in African marigold (Tagetes erecta L.) cv. Pusa Narangi Gainda. Ann. Hort. 3: 118119.

Mathew, R., Dashora, L.K. and Verma, P. 2004. Effect of growth retardants and micronutrients on growth and yield of African marigold (Tagetes erecta L.) cv. Pusa Basanti. Sci. Hort. 9: 213-218.

Muktanjali, J., Paithankar, D. H., Warade, A. D. and Anjali, T. P. 2004. Effect of nitrogen and phosphorus on China aster. $\mathrm{Adv} . \mathrm{Pl}$. Sci. 17 (1): 163-165.

Muthumanickam, D., Rajmani, K. and Jawaharlal, M. 1999. Effect of micronutrients on flower production in Gerbera. J. Orn. Hort, 2: 131-132.

Nagaich, K. N., Trivedi, S. K. and Lekhi, R. 2003. Effect of nitrogen and phosphorus on growth, flowering, yield and quality of marigold.Scientific Horticulture, 8: 203209.

Reddy, A.G.K. and Chaturvedi, O.P. 2009. Effect of zinc, calcium and boron on growth and flowering in gladiolus cv. Red Majesty. Crop Res. Hissar., 38: 135-137

Singh, A. K. and C. Singh. 2004. Effect of spacing and $\mathrm{Zn}$ on growth and flowering in gladiolus cv. Sylvia. Prog. Hort., 36(1): 94-98.

Yadav, P. K., Singh, S. and Dhindwal, A. S. 2000. Effect of nitrogen and FYM application on floral characters and yield of African marigold (Tagetes erecta L.). Hort. Sci. 29 (1-2): 69-71.

\section{How to cite this article:}

Ravindra Kumar, Ashok Kumar and Abhinav Kumar. 2018. Effect of Nutrients on Growth, Flowering and Yield of African Marigold (Tagetes erecta L.) cv. Pusa Narangi Gainda. Int.J.Curr.Microbiol.App.Sci. 7(06): 205-209. doi: https://doi.org/10.20546/ijcmas.2018.706.026 